University of Nebraska - Lincoln

DigitalCommons@University of Nebraska - Lincoln

Interferon gamma responses to proteome-determined specific recombinant proteins: Potential as diagnostic markers for ovine Johne's disease

Valerie Hughes

Susan Denham

J. P. Bannantine

Francesca Chianini

Karen Kerr

See next page for additional authors

Follow this and additional works at: https://digitalcommons.unl.edu/usdaarsfacpub

Part of the Agriculture Commons

This Article is brought to you for free and open access by the U.S. Department of Agriculture: Agricultural Research Service, Lincoln, Nebraska at DigitalCommons@University of Nebraska - Lincoln. It has been accepted for inclusion in Publications from USDA-ARS / UNL Faculty by an authorized administrator of DigitalCommons@University of Nebraska - Lincoln. 


\section{Authors}

Valerie Hughes, Susan Denham, J. P. Bannantine, Francesca Chianini, Karen Kerr, Linda May, Joyce McLuckie, Mintu Nath, and Karen Stevenson 


\title{
Interferon gamma responses to proteome-determined specific recombinant proteins: Potential as diagnostic markers for ovine Johne's disease
}

\author{
Valerie Hughes $^{\mathrm{a}, *}$, Susan Denham ${ }^{\mathrm{a}}$, John P. Bannantine ${ }^{\mathrm{b}}$, Francesca Chianini ${ }^{\mathrm{a}}$, \\ Karen Kerr ${ }^{\mathrm{a}}$, Linda May ${ }^{\mathrm{a}}$, Joyce McLuckie ${ }^{\mathrm{a}}$, Mintu Nath ${ }^{\mathrm{c}}$, Karen Stevenson ${ }^{\mathrm{a}}$ \\ a Moredun Research Institute, Pentlands Science Park, Bush Loan, Penicuik EH26 OPZ, United Kingdom \\ b National Animal Disease Center, USDA-Agricultural Research Service, Ames, IA, USA \\ c Biomathematics \& Statistics Scotland, James Clerk Maxwell Building, The King's Building, Edinburgh EH9 3JZ, United Kingdom
}

\section{A R T I C L E I N F O}

\section{Article history:}

Received 8 January 2013

Received in revised form 17 April 2013

Accepted 24 June 2013

\section{Keywords:}

Mycobacterium avium subspecies

paratuberculosis

Johne's

Cell-mediated diagnosis

Interferon gamma release assay

\begin{abstract}
A B S T R A C T
Johne's disease (JD), or paratuberculosis is a fatal enteritis of animals caused by infection with Mycobacterium avium subspecies paratuberculosis (Map). There may be a long subclinical phase with no signs of clinical disease.

Diagnosis of JD is problematic and no test can reliably detect sub-clinical disease. Th1 responses to Map are believed to be activated first with a later switch to Th2 responses and progression to clinical disease. Detection of a cell-mediated response, indicated by interferon gamma (IFN- $\gamma$ ) produced in response to mycobacterial antigens, may give an early indication of infection. Crude extracts of Map (PPDj) have been used to detect the cell-mediated response, but more specific, quantifiable antigens would improve the test.

Thirty Map-specific proteins were screened for their ability to raise a cell-mediated response in subclinically infected sheep. Four proteins were selected and tested using blood from subclinical animals and controls from a JD-free flock. Three proteins elicited IFN- $\gamma$ levels which were higher in the subclinical group than in the control group, two were statistically significant. Thus these proteins have the ability to discriminate groups of infected and uninfected animals and may have use in diagnosis of JD.
\end{abstract}

(c) 2013 Elsevier B.V. All rights reserved.

\section{Introduction}

Johne's disease (JD), or paratuberculosis, is a fatal, chronic granulomatous enteritis of animals caused by Mycobacterium avium subspecies paratuberculosis (Map), characterised by severe emaciation, poor body condition and in some species diarrhoea. The disease is mainly spread through ingestion of contaminated faecal material and following infection, a long incubation period may ensue

\footnotetext{
Abbreviations: JD, Johne's disease; IGRA, interferon gamma release assay.

* Corresponding author. Tel.: +44 (0)131 445 5111;

fax: $+44(0) 1314456111$.

E-mail address: Val.Hughes@moredun.ac.uk (V. Hughes).
}

during which there are no signs of clinical disease. These subclinical animals may go undetected and infect their herd-mates before clinical symptoms become apparent (Sweeney et al., 1992; Chiodini, 1996; Toman et al., 2003).

The diagnosis of JD is problematic and no test can reliably detect subclinical disease. Subclinical animals are particularly difficult to diagnose, they may be shedding small numbers of Map in their faeces intermittently and levels of circulating antibodies against Map may be low and not detectable by ELISA tests. PCR detection or bacteriological culture of faeces may not be sufficiently sensitive to detect low levels of organisms or may miss intermittent shedders. Thus control programmes are hampered by the inability to detect subclinical animals which fall below the radar of currently available tests. 
Early detection of Map infection is desirable to lessen the risks of transmission. The classical switch profile has been described for the immunological response of animals to Map infection (Chiodini et al., 1984; Stabel, 2000, 2006), in which Th1 responses are the first to be activated. Thus detection of a cell-mediated immune response by measuring the levels of interferon gamma (IFN- $\gamma$ ) produced in response to mycobacterial antigens (often PPD) (Wood et al., 1989) may give an early indication of subclinical animals and may occur before faecal shedding or antibodies directed against Map can be detected (Benedixen, 1978; Chiodini, 1996). A drawback to the IFN- $\gamma$ test, which is the requirement for fresh blood samples, has recently been overcome by the addition of preservatives (IL-7, IL12 and anti-IL-10), which allows a lengthened time period between collection and assay (Plain et al., 2012; Mikkelsen et al., 2012).

PPDj is a crude extract of Map and contains many antigenic components shared with the closely related environmental organism $M$. avium subspecies avium and with other pathogenic mycobacteria including $M$. bovis. Thus use of PPDj has issues for quality control and specificity. Substitution of PPD by specific recombinant proteins would greatly enhance the confidence in this test to diagnose Map infection and allow definition and quantification of antigen in the assay. Recently, Map recombinant proteins have been used to improve the specificity of the response in cattle (Mikkelsen et al., 2011). Here we describe a study to determine the efficacy of different Map recombinant proteins to elicit a Th1 response in naturally exposed sheep obtained from a flock with a history of JD and identify three recombinant proteins, which may have the ability to detect early Map infection when incorporated into an interferon gamma release assay (IGRA).

\section{Materials and methods}

\subsection{Selection of subclinically infected animals}

Subclinically infected animals were selected from two farms. Farm A had a high prevalence of ovine JD, with 27 clinical cases diagnosed between 2002 and 2008. Of these, 22 were classified as paucibacillary and the remainder as multibacillary disease following histopathological examination. Farm B had a low prevalence of JD with only one clinical case confirmed by tissue culture over the same period. The flocks on the farms were screened using the Bovigam $^{\mathrm{TM}}$ (Celtic Diagnostics Ltd, Dublin, Ireland) IGRA. Whole blood was stimulated with PPDj and incubated for $24 \mathrm{~h}$ and the IGRA was performed. Animals producing more than $400 \mathrm{pg} / \mathrm{ml}$ of IFN- $\gamma$ were considered responders and subclinically infected. These animals did not show any clinical signs of JD and were transported to the Moredun Research Institute where they were housed until the end of the study.

\subsection{Selection of control animals}

Control animals were sourced from Farm C with no history of clinical JD. Animals were negative in the following tests: Bovigam ${ }^{\mathrm{TM}}$ IGRA, JD serum ELISA and faecal culture.

\subsection{Blood collection from sheep}

Blood was collected by venipuncture in vacutainer tubes (those for IGRA contained preservative-free heparin). Experimental procedures were assessed and approved by an Experiments and Ethics Committee and authorised under the Animals (Scientific Procedures) Act 1986.

\subsection{Preparation of PBMCS}

PBMCs were prepared from buffey coat of heparinised blood using lymphoprep (Nycomed). Residual erythrocytes were removed by hypotonic lysis. PBMCs were suspended in RPMI complete (RPMI 1640 [84\%, v/v], foetal bovine serum [ $10 \%, \mathrm{v} / \mathrm{v}]$, glutamine $[1 \mathrm{mM}]$, penicillin $[100 \mathrm{U} / \mathrm{ml}]$, streptomycin $[100 \mu \mathrm{g} / \mathrm{ml}]$, gentamycin [100 $\mu \mathrm{g} / \mathrm{ml}], \beta$-mercapto ethanol [50 $\mu \mathrm{M}$ ], sodium bicarbonate $[0.08 \%, \mathrm{w} / \mathrm{v}]$, HEPES $[25 \mathrm{mM}])$, counted and adjusted to $2 \times 10^{6}$ cells per $\mathrm{ml}$.

\subsection{Incubation of blood with antigen}

Whole blood $(750 \mu \mathrm{l})$ or $500 \mu \mathrm{l}$ of PBMCs, were incubated with either PPDa (purchased from AHVLA Weybridge), PPDj or purified recombinant protein added in a volume of $50 \mu$ l to a final concentration of $2.5,2.5$ or $10 \mu \mathrm{g} / \mathrm{ml}$, respectively. ConA or SEB (final concentrations of 5 or $1 \mu \mathrm{g} / \mathrm{ml}$, respectively) were used as stimulation controls, media controls (either RPMI or PBS) were also included. Stimulated blood was incubated in $5 \%(\mathrm{v} / \mathrm{v}) \mathrm{CO}_{2}$ for $24 \mathrm{~h}$, centrifuged ( $500 \mathrm{~g}, 5 \mathrm{~min}$ at room temperature) and approx $500 \mu$ l supernatant removed and stored at $-70^{\circ} \mathrm{C}$ until required.

\subsection{Bovigam $^{\mathrm{TM}}$ IFN- $\gamma$ release assay}

The IGRAs were performed as described by the manufacturer. Ovine IFN- $\gamma$ standards ranging from 0 to $5000 \mathrm{pg} / \mathrm{ml}$ were assayed on each plate analysed. This data enabled calculation of the amount of IFN- $\gamma$ released during the stimulation. Alternatively, ODs were calibrated according to the OD-values of the positive and negative controls on the respective plates as described previously (Jungersen et al., 2002).

\subsection{JD antibody ELISA test}

Blood samples were commercially tested for serum antibody (Biobest Midlothian, UK) using the JD ELISA test (Institute Pourquier, Montpellier, France).

\subsection{Preparation of recombinant proteins}

Thirty recombinant Map proteins, previously identified as potentially Map-specific were tested. Maltose Binding Protein (MBP)-fusion recombinant proteins were cloned and purified (Hughes et al., 2008). Protein solutions were either diluted in RPMI complete for PBMC stimulation or PBS for whole blood stimulations. 


\subsection{Post mortem and histopathology}

Animals were euthanized with an intravenous injection of $100 \mathrm{mg} / \mathrm{kg}$ pentobarbital. Samples of ileum, distal jejunum (DJ), mesenteric lymph node (MLN), ileo-caecal valve (ICV) and ileo-caecal lymph node (ICLN) were collected, and fixed in $10 \%$ buffered formalin saline to be processed for histology. Samples of MLN, terminal ileum (TI) and ICLN were removed for bacteriological culture. Microscopical examination was performed on paraffinwax embedded, $5 \mu \mathrm{m}$-thick sections mounted on glass microscope slides and stained with haematoxylin and eosin (H\&E) and Ziehl-Neelsen staining (ZN) for acid-fast bacteria. Animals were classified as paucibacillary or multibacillary according to the criteria described by Clarke and Little (1996).

\subsection{Bacteriological culture from post mortem tissues}

Tissue sections (either fresh or previously frozen at $-80^{\circ} \mathrm{C}$ ) were trimmed of fat and connective tissue, homogenised, decontaminated and used to inoculate slopes of Middlebrook 7H11 supplemented with mycobactin J as described previously (Hughes et al., 2007). MLN and TI were submitted for bacteriological culture for all animals, ICLN was also submitted from W363, PC212, P7 and 4349.

\subsection{Bioinformatics}

Kyoto encyclopedia of genes and genomes (KEGG) was used to retrieve gene sequences. The SOSUI system for classification and secondary structure prediction was used to determine the likelihood of these proteins being membrane associated (Hirokawa et al., 1998).

\subsection{Statistical analysis}

Because of the small number of observations per animal and the presence of heterogeneity in variance of the status of animal, a linear model using generalised leastsquares was fitted to the OD data. The infection status of animals, recombinant protein and the interaction of these factors were fitted as categorical fixed effects. The heterogeneity in variance associated with the status of animal was explicitly modelled. The estimate of the residual variance component was obtained by the Restricted Maximum Likelihood (REML) method (Pinheiro and Bates, 2000). To take into account the multiple comparisons of several proteins, the $p$-values estimated under the fitted model for each pairwise comparison were adjusted so that the overall false discovery rate was 5\% (Benjamini and Hochberg, 1995). All statistical analyses were carried out using the R software version 2.13.1 (R Core Team, 2012).

\section{Results and discussion}

Naturally infected flocks were utilised to establish a panel of sheep identified by IGRA screening; selecting individuals with no clinical signs of disease but elevated IFN- $\gamma$ responses to PPDj. The assumption was that the selected animals had been exposed to Map and were subclinically infected. Thirty recombinant proteins were tested for their ability to elicit IFN- $\gamma$ production in PBMCs of nine subclinical sheep, results are presented in Table 1.

Animals showing production of IFN- $\gamma$ in excess of $50 \mathrm{pg} / \mathrm{ml}$ were deemed to have responded to the antigen. Responses of animals to individual proteins varied considerably, no two animals responded to the same subset. Of the 30 recombinant Map proteins investigated, all were deemed to elicit a IFN- $\gamma$ response in at least one animal. Some animals were particularly responsive to the protein antigens whilst others had limited responses. Four proteins (MAP1297, MAP1365, MAP3651c and MAP0268c), were selected for further investigation primarily on the basis of the number of animals exhibiting a response and its magnitude.

The likelihood of the selected proteins being membrane associated was determined using the SOSUI system, only MAP0268c was indicated as membraneassociated, and is a hypothetical protein with a thiopurine S-methyltransferase motif. The other proteins were predicted as soluble and annotated as phosphoribosyl isomerise (MAP1297), ornithine carbamoyltransferase (MAP1365) both involved in amino acid biosynthesis, and FADE3_2 (MAP3651c) central to terpenoid and geraniol metabolism. To assess the diagnostic potential of the selected proteins, IFN- $\gamma$ responses of subclinical and uninfected animals were compared. Six subclinical animals from Farm A (P7, P33, W363, W395, PC212, 0269) and four control animals (724A, 329A, 307A, and 463A) selected at random from Farm $C$ were used in this study. Whole blood was used rather than PBMCs for the IGRA as this would be the sample of choice for diagnostic testing. IGRAs on whole blood were carried out in duplicate with the selected proteins, MBP, and PPDa and data were analysed (Fig. 1A). The mean OD value for each blood sample tested was calibrated and corrected for the contribution of MBP to the stimulation. The data showed heterogeneity in variance for the status of infection and it was noted that the OD value of one of the animals in the infected group stimulated with MAP0268c was an order of magnitude higher than the other comparable readings and considered an outlier.

Statistical analysis of data following exclusion of the outlier (observation on animal W363 for MAP0268c) showed that the interaction effect of treatment group and protein was statistically significant $(p=0.022)$ which indicated that there was evidence of genuine differences in mean responses between the control and subclinical animal groups for some of the proteins. For all proteins, mean levels were higher in the subclinical group and the means were markedly different for MAP0268c, MAP1365 and MAP3651c. For the recombinant protein MAP3651c, the mean OD value ( \pm standard error of mean) of the infected group $(0.198 \pm 0.035)$ was statistically significantly (false discovery rate-adjusted $p=0.010$ ) higher than the mean OD value of the control group $(0.015 \pm 0.043)$. Additionally, for the protein MAP0268c, there was weak evidence (FDR-adjusted $p=0.051$ ) that the mean OD value of the infected group $(0.051 \pm 0.017)$ was higher than the mean OD value of the control group $(-0.009 \pm 0.019)$. The 
Table 1

IFN- $\gamma$ responses to recombinant Map antigens in subclinical animals.

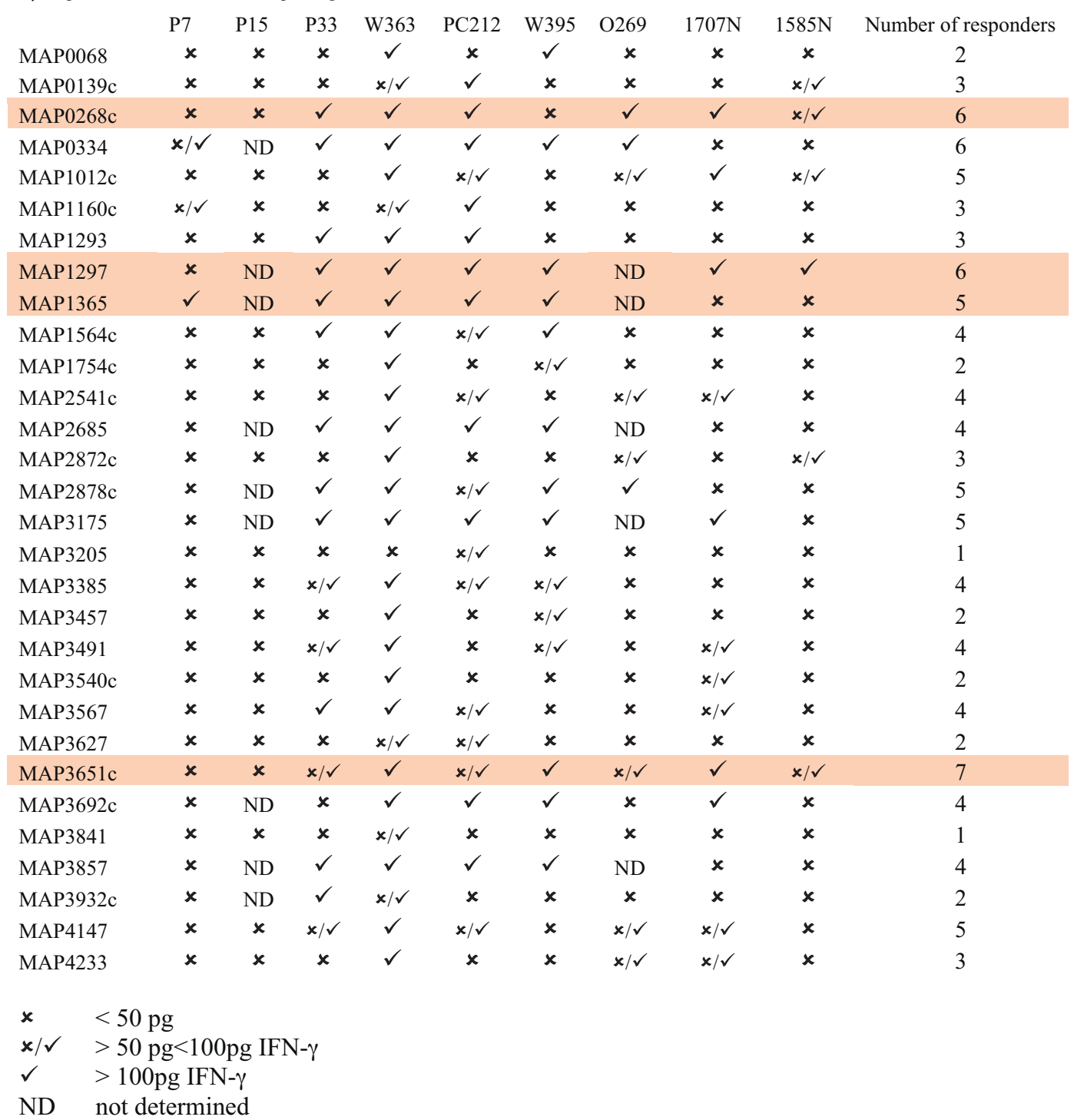

Proteins which were selected for further investigation are highlighted.

difference of the mean OD values of infected and control groups for MAP1365 was short of statistical significance $(p=0.16)$ and that for MAP1297 protein was also not statistically significant.

Inclusion of the outlying data point vastly increased the mean OD for the infected animal group but also increased the observed variation and the observed effect ceased to be statistically significant. Exclusion of the data point is not unreasonable given that technical errors in plate manipulation can lead to spurious high OD readings.

During the period of recombinant antigen testing, responses of animals to PPDj were also monitored and the results are presented in Fig. 1B. All animals (except P15) exhibited consistently high levels of IFN- $\gamma$ production in response to PPDj, although a degree of fluctuation was observed. Despite this fluctuation, most IGRA results were in excess of the arbitrary $400 \mathrm{pg} / \mathrm{ml}$ cut off we had applied in selecting the animals for investigation. Animal P15 however, demonstrated the classical IFN-gamma response pattern in JD (Stabel, 2000), in that it responded highly to PPDj in the subclinical stage (day 1-levels in excess of $500 \mathrm{pg} \mathrm{ml}^{-1}$ ), but the response was lost rapidly after transport to Moredun $\left(0-5 \mathrm{pg} \mathrm{ml}^{-1}\right)$ where it rapidly succumbed to JD 30 days after purchase.

Subclinical animals were monitored (up to 4 years) for IFN- $\gamma$ responses to PPDj and ELISA tests were performed periodically for detection of Map antibodies. Over the course of the experiment, four animals were found to have a positive JD antibody ELISA test (P15, PC212, P7 and 4349). Results of the repeated ELISA tests can be found in supplementary Table S1. 

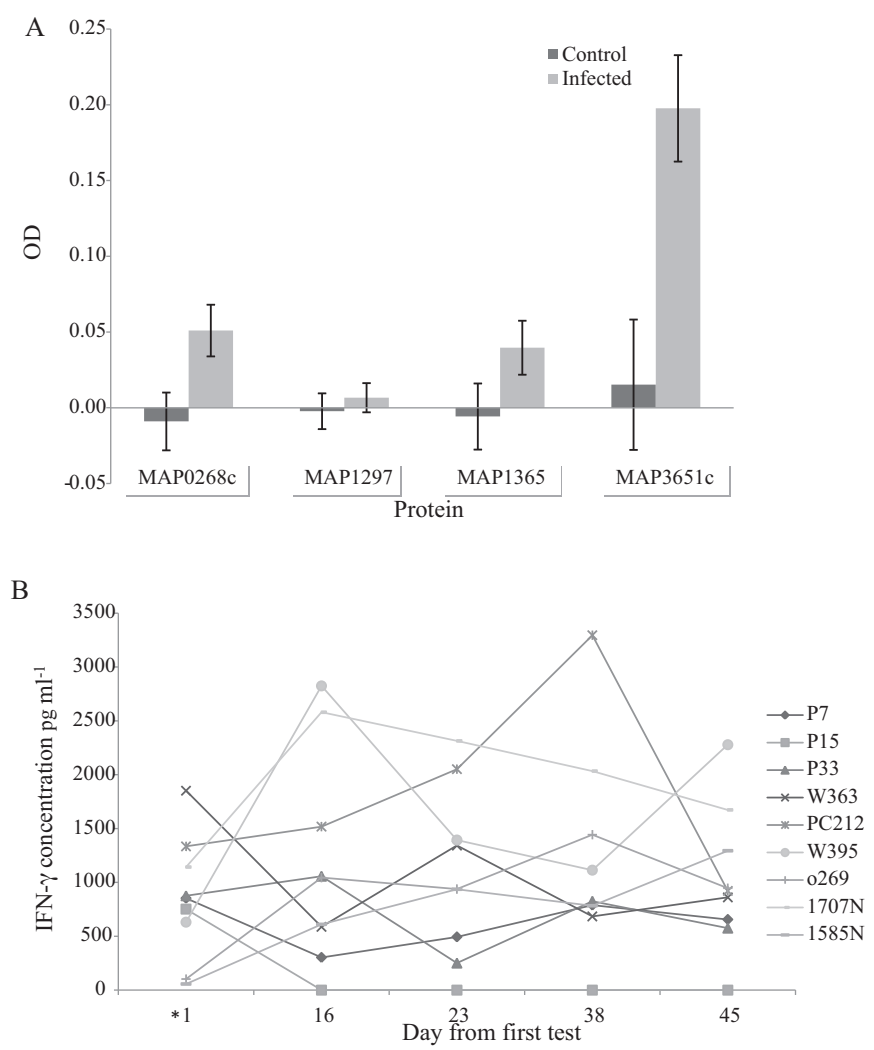

Fig. 1. (A) Mean OD values of infected and non-infected animals generated in Bovigam ${ }^{\text {TM }}$ IFN- $\gamma$ release assays. Whole blood was stimulated with four recombinant antigens (MAP268c, MAP1297, MAP1365 and MAP3651c). The infected group comprised six animals sourced from a paratuberculosis-infected flock the control group comprised four animals sourced from a flock with no history of paratuberculosis. The data was calibrated and corrected for the contribution of MBP and medium to the stimulation. The error bar indicates the standard error of mean. (B) Temporal changes in IFN- $\gamma$ production of whole blood from nine subclinical sheep in response to PPDj. OD values were generated in Bovigam ${ }^{\text {TM }}$ IFN- $\gamma$ release assays. Nine animals (P7, p15, P33, W363, PC2121, W395, O269, 1707N, 1585N) sourced from paratuberculosis-infected farms were monitored periodically. The data was corrected for the contribution of medium to the stimulation.

Supplementary material related to this article can be found, in the online version, at http://dx.doi.org/10.1016/ j.vetimm.2013.06.015.

At the end of the study period, subclinical animals were subjected to pathological and bacteriological investigations to determine their infection or disease status with respect to Map. A summary of this information including breed and age is given in Table 2 .

Histological examination of lymph nodes and intestine samples from eight subclinical sheep was carried out. Three had lesions previously described as paucibacillary (PC212, P7, 4349) and samples of their ileum and lymph nodes showed a severe infiltrate of small lymphocytes and multifocal small granulomata, with multinucleated giant cells. In animals where macroscopic nodules were observed, some of these granulomata were encapsulated and showed evidence of calcification (Fig. 2B). ZN staining of these samples did not show any acid-fast organisms. Macroscopic observations of the gastrointestinal tract showed enlarged lymph nodes in two animals (PC212 and 4349) and widespread formation of small, round, $1-2 \mathrm{~mm}$ diameter nodules on the surface of the small intestine and lymph nodes of two sheep (P7 and 4349) (Fig. 2A). One had lesions consistent with multibacillary JD (P15) (Fig. 2C and D), changes in the ileum were characterised by sheets of closely packed macrophages with abundant, weakly eosinophilic cytoplasm, mainly seen in the mucosa. A milder similar infiltrate was observed in the lamina propria, submucosa and in the lymph nodes. ZN staining demonstrated a large number of acid-fast rods in the cytoplasm of macrophages (Fig. 2D). Two further animals (0269 and W395) had an inflammatory infiltrate characterised by large amounts of eosinophils, some neutrophils and small mineralised abscesses. The samples from the remaining two animals (W363 and P33) were within normal histological limits (Table 2). The significance of the small, mineralised nodules observed macroscopically on the surface and within the tissues was difficult to determine. Similar lesions were reported previously in JD, but were attributed to parasitic infection (Pérez et al., 1996). However, the cases described here had low parasitic loads and an absence of parasitic debris. Mineralisation of lymph node lesions has been described previously in JD-affected wild ruminants (Williams et al., 1983; de Lisle et al., 1993) so it is not implausible that the mineralised nodules observed in this study were pathological lesions of JD.

Animal PC212 was one of the higher producers of PPDj-stimulated IFN- $\gamma$ and had concomitant high levels 
Table 2

Summary of the post mortem pathological and bacteriological observations in the subclinical animals.

\begin{tabular}{|c|c|c|c|c|c|c|c|c|}
\hline & W363o & PC212ㅇ & P7o & $43499^{\mathrm{b}}$ & 0269우 & W395ㅇ & P33o & $\mathrm{P} 15^{\mathrm{a}} \mathrm{q}$ \\
\hline General condition & Good & Good, but thin & $\begin{array}{l}\text { Good, but } \\
\text { moderately } \\
\text { thin }\end{array}$ & Good & Good & Good & Good & Scouring and very thin \\
\hline FEC & 0 & 0 & 0 & 0 & 0 & 0 & 0 & $\operatorname{High}(6750 / \mathrm{g})$ \\
\hline Breed & $\begin{array}{l}\text { Bleu du } \\
\text { Maine X }\end{array}$ & $\begin{array}{l}\text { Bleu du } \\
\text { Maine X }\end{array}$ & $\begin{array}{l}\text { Bleu du } \\
\text { Maine X }\end{array}$ & $\begin{array}{l}\text { Bleu du } \\
\text { Maine X }\end{array}$ & $\begin{array}{l}\text { Bleu du } \\
\text { Maine }\end{array}$ & $\begin{array}{l}\text { Bleu du } \\
\text { Maine }\end{array}$ & Bleu du Maine X & Lleyn $\mathrm{X}$ \\
\hline Age (yrs) at PM/death & 8 & 8 & 7 & 6 & 7 & 6 & 5 & 3.5 \\
\hline Gross pathology & $\begin{array}{l}\text { GI tract, ICLN \& } \\
\text { MLN normal }\end{array}$ & $\begin{array}{l}\text { Gl tract normal } \\
\text { Enlarged ICLN } \\
\text { \& MLN }\end{array}$ & $\begin{array}{l}\text { Wide spread } \\
\text { cysts/nodules } \\
\text { on surface of GI } \\
\text { tract, ICLN \& } \\
\text { MLN and liver }\end{array}$ & $\begin{array}{l}\text { Some } \\
\text { cysts/nodules } \\
\text { on surface of GI } \\
\text { tract, ICLN, } \\
\text { MLN \& liver } \\
\text { MLN enlarged } \\
\text { with single cyst }\end{array}$ & $\begin{array}{l}\text { GI tract, ICLN \& } \\
\text { MLN appeared } \\
\text { normal }\end{array}$ & $\begin{array}{l}\text { GI tract, ICLN \& } \\
\text { MLN appeared } \\
\text { normal }\end{array}$ & $\begin{array}{l}\text { GI tract, ICLN \& MLN } \\
\text { appeared normal }\end{array}$ & $\begin{array}{l}\text { GI tract appeared } \\
\text { normal, enlarged MLN } \\
\text { and ICLN }\end{array}$ \\
\hline Histopathology & $\begin{array}{l}\text { No significant } \\
\text { lesions in the } \\
\text { intestine or } \\
\text { lymph nodes. }\end{array}$ & $\begin{array}{l}\text { Inflammatory } \\
\text { infiltrate of IM, } \\
\text { DJ, ICV and } \\
\text { liver } \\
\text { (eosinophils } \\
\text { and giant cells) } \\
\text { multifocal } \\
\text { small } \\
\text { granulomata, } \\
\text { encapsulated } \\
\text { with } \\
\text { calcification }\end{array}$ & $\begin{array}{l}\text { Inflammatory } \\
\text { infiltrate of IM, } \\
\text { DJ, ICV, LN and } \\
\text { liver } \\
\text { (eosinophils } \\
\text { and giant cells) } \\
\text { multifocal } \\
\text { small } \\
\text { granulomata, } \\
\text { encapsulated } \\
\text { with } \\
\text { calcification }\end{array}$ & $\begin{array}{l}\text { Inflammatory } \\
\text { infiltrate J and } \\
\text { DJ LN } \\
\text { eosinophills } \\
\text { and giant cells } \\
\text { IM and ICV } \\
\text { normal }\end{array}$ & $\begin{array}{l}\text { Inflammatory } \\
\text { infiltrate in IM } \\
\text { \& ISM mainly } \\
\text { eosinophil, } \\
\text { some } \\
\text { neutrophil. Old } \\
\text { abscesses in LN }\end{array}$ & $\begin{array}{l}\text { Inflammatory } \\
\text { infiltrate in IM } \\
\text { \& ISM mainly } \\
\text { eosinophil, } \\
\text { some } \\
\text { neutrophil. } \\
\text { Old abscess in } \\
\text { LN }\end{array}$ & $\begin{array}{l}\text { No significant changes } \\
\text { in the IM or LN. }\end{array}$ & $\begin{array}{l}\text { Inflammatory infiltrate } \\
\text { (severe) of IM \& ISM } \\
\text { (macrophage, some } \\
\text { eosinophil) } \\
\text { LN moderate numbers } \\
\text { macrophage }\end{array}$ \\
\hline Map isolated from tissues & No & +TI, ICLN & +TI, MLN, ICLN & +TI, MLN & No & No & No & $\mathrm{ND}^{c}$ \\
\hline Diagnosis & Normal & Paucibacillary & Paucibacillary & Paucibacillary & $\begin{array}{l}\text { Parasitic } \\
\text { infection }\end{array}$ & $\begin{array}{l}\text { Parasitic } \\
\text { infection }\end{array}$ & Normal & Multibacillary \\
\hline
\end{tabular}

FEC, faecal egg count; Strongylata, Nematodirus and Coccidia were identified in faecal material; TI, terminal Ileum; IM, ileal mucosa; ISM, ileal submuscosa; LN, lymph node; DJ, distal jejunum; ICLN, ileo-caecal lymph node; ICV, ileo-caecal valve; MLN, mesenteric lymph node.

a Died.

b Animal recruited late to study and not used for screening recombinant antigens.

c Not done, however,large numbers of acid fast bacilli were noted in IM, ISM and LN and faeces was culture positive for Map. 

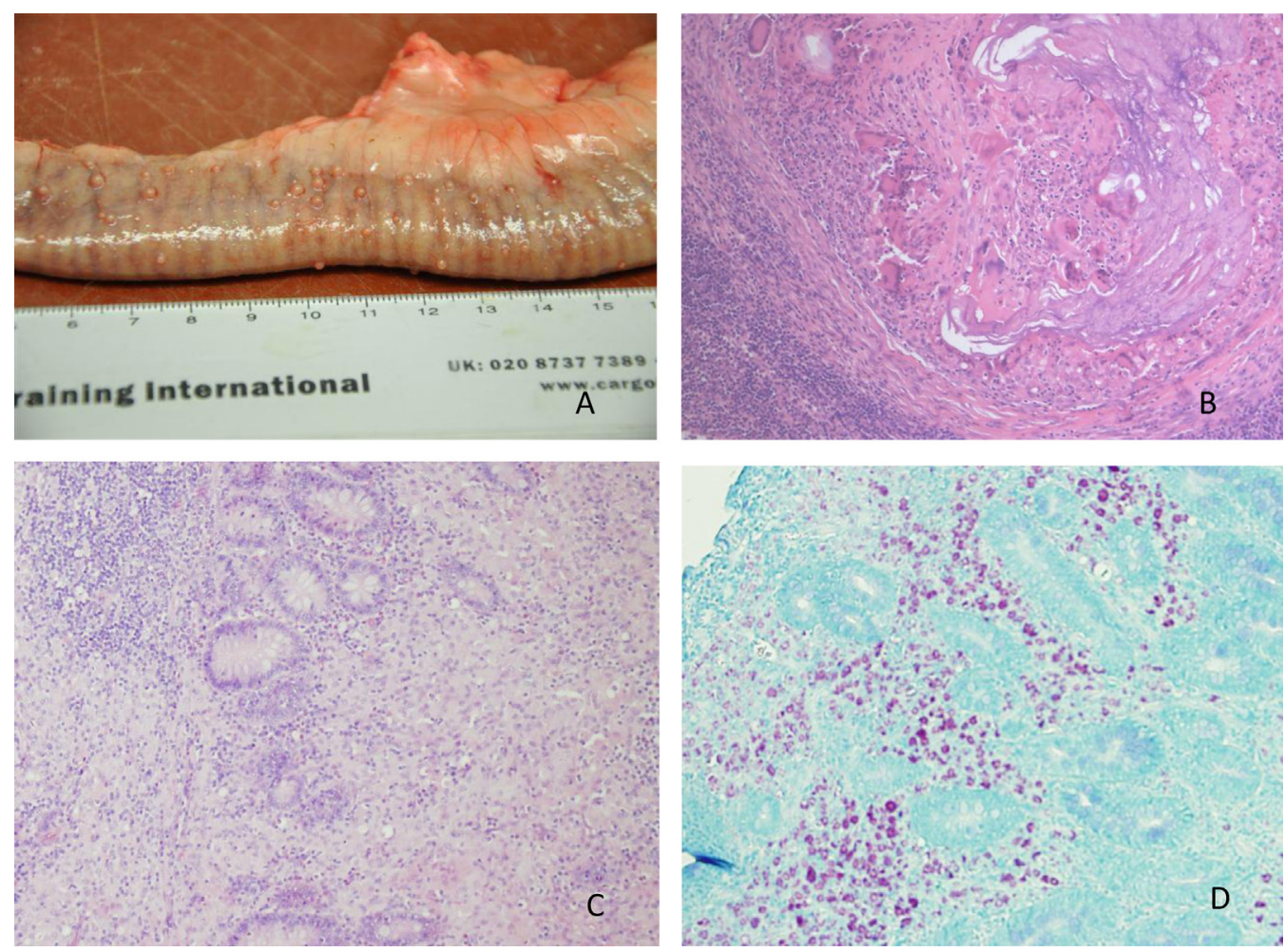

Fig. 2. (A) Ileum of sheep P7 showing macroscopical widespread 1-2 mm diameter nodules and microscopical encapsulated granuloma (B) with numerous multinucleated giant cells and calcification (H\&E, original magnification $\times 200)$. (C) Multibacillary paratuberculosis (P15): very large number of macrophages with abundant cytoplasm infiltrating ileal mucosa $(\mathrm{H} \& \mathrm{E}$, original magnification $\times 200)$ and (D) stained with $\mathrm{ZN}($ original magnification $\times 200)$.

of antibody. This case shows that high levels of antibody can exist alongside a well developed Th1 response, which goes against the dogma of the switch hypothesis (Chiodini et al., 1984; Stabel, 2000, 2006) and supports the temporally coincident antibody/IFN- $\gamma$ responses for some animals with JD as previously reported (Begg et al., 2011).

The ability of these proteins to discriminate between subclinical and control animals indicates their potential as diagnostic tools in IGRAs for the detection of subclinical infections in sheep and their identification is a step towards a better diagnostic tool for JD. The mean OD values of all antigens were lower than that obtained for PPDj stimulation of the infected group (0.7) which indicates that the complex antigenic mix of PPDj was a more powerful stimulant of IFN- $\gamma$ production than any of the recombinant antigens. However, a mixture of the three antigens in a single IGRA increased the magnitude of response and was effectively the sum of the individual parts (authors unpublished observations). This indicates that cocktails of recombinant proteins maybe necessary to develop future sensitive diagnostic tests. Although specificity of these proteins is implied, an empirical approach to test the specificity of an IGRA incorporating these proteins is still required.

The application of the IFN- $\gamma$ test for detection of individual animals likely to progress to clinical disease is still debatable. Global differences of IFN- $\gamma$ response to PPD in exposed and non-exposed populations was clearly demonstrated (Jungersen et al., 2012), but its ability to predict shedding or clinical disease in individual animals was not
(Huda et al., 2004; Mikkelsen et al., 2009). In our study, four out of eight sheep with elevated IFN- $\gamma$ release (in excess of $400 \mathrm{pg} / \mathrm{ml}$ ) either had a positive diagnosis of paratuberculosis as defined by the serum antibody ELISA or progressed to it within the time scale of the experiment (2-3 years). This high proportion of IGRA test positive animals which progressed to diagnosis by the classical serum ELISA test appears to be at odds with previous findings (Huda et al., 2004). The likelihood of an exposed animal (as defined by IFN- $\gamma$ response) developing detectable infection (either faecal shedding or a positive serum ELISA test) and the impact of external factors is yet to be defined and crucial for determining the efficacy of the IGRA to act as a prognostic for JD.

A major drawback in control and eradication of JD is the lack of tools to identify early-stage infections. Generation of tools to monitor exposure of individual animals to Map may provide a starting point to understand disease progression and in ovine cases, may have applications in indicating animals which should be removed from flocks to control the spread of disease.

\section{Acknowledgements}

This work was funded by the Scottish Government Rural and Environment Science and Analytical Services Division and Genecom.

PPDj was supplied as a kind gift from Douwe Bakker, Central Veterinary Institute, Lelystad, The Netherlands. 
Ovine IFN- $\gamma$ was kindly supplied by Sean Wattegedera and Gary Entrican, supported by the Scottish Government RESAS and by BBSRC grant number BBI019863/1).

\section{References}

Begg, D.J., de Silva, K., Carter, N., Plain, K.M., Purdie, A., Whittington, R.J., 2011. Does a Th1 Th2 dominancy really exist in the early stages of Mycobacterium avium subspecies paratuberculosis infections? Immunobiology 216, 840-846.

Benedixen, P.H., 1978. Immunological reactions caused by infection with Mycobacterium paratuberculosis-a review. Nord. Vet. Med. 30, 163-168.

Benjamini, Y., Hochberg, Y., 1995. Controlling the false discovery rate: a practical and powerful approach to multiple testing. J. R. Stat. Soc., Ser. B 57, 289-300.

Chiodini, R.J., Van Kruiningen, H.J., Merkal, R.S., 1984. Ruminant paratuberculosis (Johne's disease): the current status and future prospects. Cornell Vet. 74, 218-262

Chiodini, R.J., 1996. Immunology: resistance to paratuberculosis. Vet. Clin. N. Am. Food Anim. Pract. 12, 313-343.

Clarke, C.J., Little, D., 1996. The pathology of ovine paratuberculosis: gross and histological changes in the intestine and other tissues. J. Comp. Pathol. 114, 419-437.

de Lisle, G.W., Yates, G.F., Collins, D.M., 1993. Paratuberculosis in farmed deer: case reports and DNA characterization of isolates of Mycobacterium paratuberculosis. J. Vet. Diagn. Invest. 5, 567-571.

Hirokawa, T., Boon-Chieng, S., Mitaku, S., 1998. SOSUI: classification and secondary structure prediction system for membrane proteins. Bioinformatics $14,378-379$.

Huda, A., Jungersen, G., Lind, P., 2004. Longitudinal study of interferongamma, serum antibody and milk antibody responses in cattle infected with Mycobacterium avium subsp. paratuberculosis. Vet. Microbiol. 104, 43-53.

Hughes, V., Smith, S., Garcia-Sanchez, A., Sales, J., Stevenson, K., 2007. Proteomic comparison of Mycobacterium avium subspecies paratuberculosis grown in vitro and isolated from clinical cases of ovine paratuberculosis. Microbiology 153, 196-205.

Hughes, V., Bannantine, J.P., Denham, S., Smith, S., Garcia-Sanchez, A Sales, J., Paustian, M.L., Mclean, K., Stevenson, K., 2008. Immunogenicity of proteome-determined Mycobacterium avium subsp. paratuberculosis-specific proteins in sheep with paratuberculosis. Clin. Vaccine Immunol. 15, 1824-1833.

Jungersen, G., Huda, A., Hansen, J.J., Lind, P., 2002. Interpretation of the gamma interferon test for diagnosis of subclinical paratuberculosis in cattle. Clin. Diagn. Lab. Immunol. 9, 453-460.
Jungersen, G., Mikkelsen, H., Grell, S.N., 2012. Use of the johnin PPD interferon-gamma assay in control of bovine paratuberculosis. Vet. Immunol. Immunopathol. 148, 48-54.

Mikkelsen, H., Aagaard, C., Nielsen, S.S., Jungersen, G., 2012. Correlation of antigen-specific IFN-g responses of fresh blood samples from Mycobacterium avium subsp. paratuberculosis infected heifers with responses of day-old samples co-cultured with IL12 or anti-IL-10 antibodies. Vet. Immunol. Immunopathol. 147, 69-76.

Mikkelsen, H., Aagaard, C., Nielsen, S.S., Jungersen, G., 2011. Novel antigens for detection of cell mediated immune responses to Mycobacterium avium subsp. paratuberculosis infection in cattle. Vet. Immunol. Immunopathol. 143, 46-54.

Mikkelsen, H., Jungersen, G., Nielsen, S.S., 2009. Association between milk antibody and interferon-gamma responses in cattle from Mycobacterium avium subsp. paratuberculosis infected herds. Vet. Immunol. Immunopathol. 127, 235-241.

Pérez, V., García Marín, J.F., Badiola,J.J., 1996. Description and classification of different types of lesion associated with natural paratuberculosis infection in sheep. J. Comp. Pathol. 114, 107-122.

Pinheiro, J.C., Bates, D.M., 2000. Mixed-effects Models in S and S-Plus. Springer, New York.

Plain, K.M., Begg, D.J., de Silva, K., Purdie, A.C., Whittington, R.J., 2012. Enhancement of the interferon gamma assay to detect paratuberculosis using interleukin-7 and interleukin-12 potentiation. Vet. Immunol. Immunopathol. 149, 28-37.

R: A Language and Environment for Statistical Computing, R Foundation for Statistical Computing, Vienna, Austria. ISBN 3-900051-07-0 http://www.R-project.org/

Stabel, J.R., 2000. Transitions in immune responses to Mycobacterium paratuberculosis. Vet. Microbiol. 77, 465-473.

Stabel, J.R., 2006. Host responses to Mycobacterium avium subsp. paratuberculosis: a. complex arsenal. Anim. Health Res. Rev. 7, 61-70.

Sweeney, R.W., Whitlock, R.H., Rosenberger, A.E., 1992. Mycobacterium paratuberculosis cultured from milk and supramammary lymph nodes of infected asymptomatic cows. J. Clin. Microbiol. 30, 166-171.

Toman, M., Faldyna, M., Pavlik, I., 2003. Immunological characteristics of cattle with Mycobacterium avium subsp. paratuberculosis infection. Vet. Med. 48, 147-154

Williams, E.S., Snyder, S.P., Martin, K.L., 1983. Pathology of spontaneous and experimental infection of North American wild ruminants with Mycobacterium paratuberculosis. Vet. Pathol. 20, 274-290.

Wood, P.R., Kopsidas, K., Milner, A.R., Hill, J., Gill, I., Webb, R., Mack, W.N., Coates, K., 1989. The development of an in vitro cellular assay for Johne's disease in cattle. In: Milner, A.R., Wood, P.R. (Eds.), Johne's Disease: Current Trends in Research, Diagnosis and Management. CSIRO Publications, East Melbourne, Australia, pp. 164-167. 